\title{
Student Workload and Degree Profiles: the experience of CLAR credit in Latin America
}

\author{
Francisco Alarcón, Pablo Beneitone, Roberto de Armas, \\ Sérgio Kieling, Letícia Suñé, and Diana Veneros
}

\begin{abstract}
There is growing consensus in Latin America on the necessity to reorganize the degree profiles in a competence-based and student-centred system, with identified learning outcomes, innovative learning and teaching strategies, and new methodologies for assessing competences which could be useful for students. There is also agreement on the need to build up a solid Latin America Higher Education Area - based on common benchmarks - among which a shared regional academic credit system is highly relevant. Not all Latin American higher education institutions are familiar with an academic credit system. In the countries where academic credits do exist they are generally based on traditional views which focus on teaching and transmission, rest on different concepts and definitions and consider diverse scopes for their application. With few exceptions, these countries do not use a credit system as a unit of measure of student workload to achieve learning outcomes and competences. This paper sheds light on a proposal for a common academic credit system for Latin America (CLAR) which comes out of one of the many nuances of Tuning discussion and is referred to the expected outcome 6: "Political-and educational orientations for the establishment of a system of academic credits for Latin America". 1

The new credit system that this paper advocates for Latin America is based on the principle that 60 credits measure the workload of a full-time student during one academic year. As such, a CLAR credit is conceived as a unit of value that estimates the student workload, measured in hours, which he/she typically requires to achieve learning outcomes and pass a course or a semester.

In order to calculate the value of CLAR credit two elements are considered: the duration of the academic year and the annual student workload. To estimate the annual student workload, a specific survey was applied in 18 countries, 189 universities and 15 subject areas. This paper shows the major results that were brought out by 10,086 questionnaires, which were responded to by students and university professors. As a result of this survey, the student workload of a full-time study programme in Latin America amounts to around 1,440 to 1,980 hours per year and in those cases one credit stands for around 24 to 33 working hours.
\end{abstract}

Keywords: student workload; credit system; CLAR; degree profiles; Latin America.

\footnotetext{
${ }^{1}$ Proyecto Alfa Tuning América Latina: Innovación Educativa y Social, 2011-2013.
} 


\section{New context, new needs}

The world is undergoing rapid changes due to an unprecedented scientific and technological development which has made familiar the notions of "society of knowledge' and 'globalization'. In this new context, higher education and universities all over the world face new demands. On the one hand, graduates must comply with new professional standards and confront the ever-changing demands and expectations of global labour markets and societies. It is now widely accepted that an apt, innovative and skilled workforce is a key component of nations' wealth, competitiveness and prosperity. In contrast, graduates' disciplinary knowledge - which has been the main component of a traditional higher education - proves to be insufficient. It is has been argued that a full knowledge acquisition does not necessarily assure the successful application of the same knowledge. ${ }^{2}$ Societies require that new professionals also have analytical and reflective skills and the ability to solve in a creative manner conflicts and problems, whether personal or professional. To sum up, new developments have not only led to a different view of knowledge, but also to an increased concern for the acquisition of competences and for a competence based education and training. ${ }^{3}$

A broad definition of competence might conceive it as the capacity that all humans need to solve, in effective and autonomous ways, the problems and situations that arise in their lives. A competence is grounded on a deep knowledge - not only on knowing what and how-but also on knowing how to be a person in a complex, changing and competitive world. Another definition suggests that competences are "complex integrated capacities, in different gradations, in which education must train individuals so that they can operate as responsible subjects in different situations and contexts of their social and personal life, knowing how to see, do, act and enjoy properly, assessing alternatives, choosing appropriate strategies and taking responsibility for the decisions taken". ${ }^{4}$

${ }^{2}$ S.E.M. Everwijn, G.B. Bomers, and J.A. Knuben, "Ability or Competence-Based Education: Bridging the Gap between Knowledge Acquisition and Ability to Apply," Higher Education 25, no. 4 (1993): 425-38.

3 Wim Kouwenhoven, "Competence-Based Curriculum Development in Higher Education: A Globalised Concept?" In Technology Education and Development, edited by Aleksandar Lazinica and Carlos Calafate (Vukovar: In-Tech, 2009), http://www.intechopen. com/books/technology-education-and-development/competence-based-curriculumdevelopment-in-higher-education-a-globalised-concept-.

${ }^{4}$ Carlos Cullen, "El Debate Epistemológico de fin de Siglo y su Incidencia en la Determinación de las Competencias Científico Tecnológicas en los Diferentes Niveles de la Educación Formal. Parte II," in Novedades Educativas $N^{\circ}$ 62, Buenos Aires, 1996, http://www. oei.es/n4003.htm. 
Gardner, speaking on the notion of multiple intelligences, argues that competences are neither innate nor predetermined.$^{5}$ No one is born predestined to develop a specific competence. People, as intelligent beings, are capable of preparing constructions based on the demands from their surroundings, which provide them with multiple different stimuli. They can thus manage to develop specific capacities. People who bring new perspectives to their social as well as to their productive lives are those who are able to identify problems, analyse them, find their "roots", propose solutions and implement them successfully. They count on personal characteristics that allow them to live harmoniously in different environments while preserving their inner balance.

A competence-based education has been deemed apt as a means to instruct individuals so that they can suitably act as proficient, creative and responsible subjects in different situations and contexts of their social, productive and personal life. It has also been considered as a tool to eliminate the barriers that exist between the spheres of daily family life, formal learning, workplace and community. By interlacing a thread between everyday knowledge, academic knowledge, 'know-how' knowledge and scientific knowledge, it is possible to count on a comprehensive education encompassing knowledge (cognitive capacities), abilities (sensory-motor capacities), skills, attitudes and values. The elimination of borders between formally and non-formally acquired knowledge enables the recognition of the value of multiple sources of knowledge, such as personal experience, prior learning in different areas of each person's life, imagination, art and creativity. In the last resort, what an individual should develop in life, and for life, are capacities to increase "know" (savoir) and "know-how" (savoir faire) and to act responsibly, resourcefully and in a collaborative fashion in the community and the workplace (savoir être).

As far as higher education is concerned, it has been stated that it is necessary to bridge the gap between a 'traditional education' - based on disciplinary knowledge and transmission - and a competence-based education required for the new global job market and the new society of knowledge. ${ }^{6}$ In general, the dominant transmissional approach does not adequately prepare learners for work, further or higher education, or life in general. It needs to be replaced by a new model based on a student-centred learning approach that

${ }^{5}$ Howard Gardner, Inteligencias Múltiples. La Teoría en la Práctica (Barcelona: Paidós, 1995).

${ }^{6}$ Rodrigo Arocena and Judith Sutz, "Changing Knowledge Production and Latin American Universities," Research Policy 30, no. 8 (2001): 1221-34. 
moves education from focusing on what academics believe graduates need to know (teacher-focused) to what students need to know and be able to do in varying and complex situations (student and/or workplace focused). In this new model lecturers act as facilitators, study guides help the learners to organize their learning activities as well as to be responsible for their learning achievements, group work complements individual work, and continuous assessment and self-assessment are major features. ${ }^{7}$

How have Latin American universities reacted to this challenge? As in the majority of developing countries, higher education institutions in Latin American are still dominated by the concept and praxis of a 'traditional education' that emphasize the transmission of disciplinary contents and the paramount role of professors inside the classroom. This traditional education tends to focus on what and how learners are taught and less so on whether or not they can use their learning to solve problems, perform procedures, communicate effectively, or make good decisions.

However, higher education institutions are not impermeable to change. The need to face social scrutiny and meet the new productive demands is paving the way for them to reflect upon issues that until now have been taken for granted.

There is in fact a widespread debate which revolves around relevance ${ }^{8}$ and quality. ${ }^{9}$ As far as relevance is concerned, one of the main issues under discussion is if the training processes actually prepare proficient, reflective and creative professionals and individuals who are able to contribute to their own self-education. Another issue relates to the role of the student and the professor in the classroom and what should be the optimal relationship between them, and how this could contribute to a more effective learning. From this fertile debate which involves psychological, pedagogical, didactic and methodological aspects, a main conclusion emerges: it is necessary to abandon the traditional concept of a teacher-centred education, understood as the transmission and acquisition of content. It is necessary to act with new

${ }^{7}$ K. Reddy, "The Inclusion of Technology as a Subject in the National Curriculum. A Significant Paradigm Shift for Education in South Africa," MEd thesis, University of Pretoria, 1995. Cited in SPT Malan, "The 'New Paradigm' of Outcomes-Based Education in Perspective," Tydskrif vir Gesinsekologie en Verbruikerswetenskappe (Journal of Family Ecology and Consumer Sciences) 28 (2000): 22 - 28.

${ }^{8}$ Luis Enrique Orozco Silva, "Calidad Académica y Relevancia Social de la Educación Superior en América Latina," Revista Iberoamericana de Educación Superior (RIES) 1, no. 1 (2010): 24-36.

9 José J. Brunner, “Aseguramiento de la Calidad y Nuevas Demandas sobre la Educación Superior en América Latina," in Educación Superior. Desafío Global y Respuesta Nacional, edited by Luis Enrique Orozco (Bogotá: Universidad de los Andes, 2001). 
concepts and with a clear focus on the learning process and its results and on the student.

Yet, if it is true that the need for innovation in the teaching and learning process is paving its own way, there are still many uncertainties about how this may be best achieved. To switch the traditional focus from teaching to learning is not easy since it implies the assumption of new curriculum concepts that should lead and assure an effective learning. Gil ${ }^{10}$ highlights three independent factors that influence learning: the student, the professor and the course. As for students, individual characteristics on the intellectual level and the specific skills and values previously developed by him or her explain the different performances observed in diverse educational contexts. Motivation is also a determining factor in the success of learning as well as the study habits displayed by students, including workload, that influence the final result. Furthermore, the professor is a factor that greatly influences learning outcomes: the level of knowledge on the subject, pedagogical and didactic skills, motivation and the ability to structure the learning situation in terms of capacity building of his/her students, are key aspects for achieving the desired learning outcomes. On the role of learning in the course structure, it is obvious that there is a strong relationship between learning and the objectives and organization of a course. Therein lies the concept that guides the implementation of the activities of a course in order to induce learning outcomes. The set curriculum-teaching process is thus the most direct way to accomplish what is central to the university: student learning. When we think of innovative curricula that leads professors to act with a focus on learning and encourage students to use their training in the best way, we must also think of the elements in the curriculum design which will achieve these purposes.

In a student-centred teaching and learning process, and if students are supposed to become effective learners, one of the most important issues to deal with is the time required for them to localize and process the information received, internalize, reflect and construct their own meanings to transform this information into knowledge and mobilize and contextualize this knowledge in simulated situations or practices that permit the consolidation of learning. It is essential to take into account the time spent by students in independent studies along with hours of classroom activities, laboratories, workshops, internships, among others.

Therefore, innovative programs must estimate adequately the workload required for students to achieve the learning outcomes specified in the

${ }^{10}$ Antonio Carlos Gil, Didática do Ensino Superior, 1th ed. (São Paulo: Atlas, 2008). 
curriculum. In this sense, the adoption of credits to consider the total amount of student workload - not just associated to formal activities - is a process that actually innovates in the teaching and learning process and induces the implementation of a student-centred curriculum in Latin American universities.

\section{Credits and Latin America: a history of disagreements}

Until 2012 there was no academic credit system shared by all Latin American countries. Moreover, higher education institutions in the region are still rather unfamiliar with a credit system purported to support curricular change and lead the shift towards a student-centred and competence-based higher education. In the countries where academic credits do exist, they are generally based on traditional views which focus on teaching and transmission, resting on different concepts and definitions and consider diverse scopes for their application.

It is worth noting, for example, that in some Latin American countries where academic credits are in place these have been implicitly conceptualized keeping in mind the teaching process performed by professors in the classroom or in direct contact with students through supervised activities. In practice, the central element of this approach is the professorial workload. Thus, although the definition of credit does not formally declare it, institutions have been using credits as a means to estimate professors' workload and value their salary or fees.

Even though some commonalities exist - especially in Central America - credit definitions and equivalence vary considerably from one country to another in Latin America. ${ }^{11}$ Thus one credit can stand for 15 hours, 16 hours, 20 hours, 25 hours, 30 hours, 45 hours, 48 hours, etc. However, the most common situation is a credit that is equivalent to one contact hour per week for 15 or 16 weeks per semester and that for every contact hour estimates independent work of two hours (around 45 and 48 hours per credit).

Despite some differences among countries, and in general terms, the allocation of credits is mostly made taking into consideration classroom work and contact hours. This criterion assigns professors a more active role

${ }_{11}$ Tuning Latin America Project (Tuning Latin America), "Working Papers - Tuning Latin America Document 2." 2nd General Meeting. Guatemala, 18 - 20 November 2011, http://www.tuningal.org/es/publicaciones/cat_view/42-presentaciones-reunion-guatemala-1619-nov-2011. 
(«teaching») whereas inversely students have a more passive one («listening and receiving") in a master class or tutorial session). Practical activities for students such as laboratories, workshops and field activities are utterly undervalued - even more than independent student work (home study, research, internships, etc.). It is common that 1 contact hour per week is required to achieve 1 credit but at least 2 or 3 hours per week of practical work and activities (laboratories, workshops, fieldwork) to obtain the same credit.

In the countries where students' independent work is prized, a credit's value is estimated arbitrarily on the basis of time spent by students in contact hours. As already mentioned, the criterion being used assumes that for every hour of classroom work the student should spend two hours doing independent work. It is well known that this relationship is not based on theories or field studies. Yet, as it stands as a reasonable and convenient assumption it has been widely accepted.

In short, the conceptualization and definition of an academic credit in Latin American countries (except in Chile ${ }^{12}$ ), has not been associated with either an estimation of total student workload (measured in hours) or to a fixed number of credits per year. As for its value, this has been generally allocated in accord with the type of academic activity done by students or with them instead.

\section{Tuning in Latin America ${ }^{13}$ : a contribution to the curriculum modernization}

As in other developing regions, Latin American higher education institutions have initiated a transition from a traditional teaching-centred approach based on the transmission and acquisition of contents towards a new approach focused on the learning process, learners' needs and expectations and students' ability to learn. There is also a growing consensus on the necessity to reorganize the degree profiles in accord with this studentcentred, competence-based system, with identified learning outcomes, innovative learning and teaching strategies, and comprehensive methodologies to assess learning outcomes and competences.

Since its inception in 2004, the Tuning Latin America project has sought to contribute significantly to the innovation of higher education systems in

${ }^{12}$ Consejo de Rectores de Universidades Chilenas (CRUCH), Guía Práctica para la Instalación del Sistema de Créditos Académicos Transferibles (SCT-Chile) (Santiago de Chile: MECESUP, 2007).

13 Tuning Latin America website: http://www.tuningal.org/ 
the region, creating tools and capabilities to support and facilitate this transition while contributing to establish the landmarks for the construction of a higher education common area in Latin American. This construction involves the need to establish common benchmarks, among which the definition of a shared academic credit for Latin America is relevant.

However, as the academic credit systems in place in Latin American higher education institutions are diverse and mostly linked to a traditional view of education focused on teaching and transmission of contents, it does not seem appropriate and sufficient to promote harmonization from the existing concepts and practices.

The Tuning project, focused on generic and specific competences and learning outcomes has shown that approaches to learning, teaching and assessment significantly affect the work that students need to do in order to achieve the desired learning outcomes; hence it also affects how they measure themselves. Student workload, teaching methods and competences and learning outcomes are all clearly interrelated. Nevertheless, other factors also have an influence, such as the diversity of university cultures and educational traditions, design of the study plan, consistency of the study programmes, organisation of teaching, and the capacity and attitude of the students. In other words, the time that students require in order to achieve the same competences and learning outcomes may substantially vary depending on the particular context in which this process takes place..$^{14}$ It is therefore important to establish a baseline credit system that enables the measurement of this time and its recognition.

Given the need to reflect in context on the time that students require in order to achieve competences and learning outcomes, the Tuning Latin America project in its second phase (2011-2013) led an extensive study in 15 subject areas (Agronomy, Architecture, Business, Chemistry, Computer Sciences, Civil Engineering, Education, Geology, History, Law, Nursing, Mathematics, Medicine, Physics, and Psychology). This study was developed in 189 universities from 18 Latin American countries (Argentina, Bolivia, Brazil, Costa Rica, Colombia, Cuba, Chile, Ecuador, El Salvador, Guatemala, Honduras, Nicaragua, Mexico, Panama, Paraguay, Peru, Venezuela and Uruguay). Between November 2011 and March 2012, a large survey labelled "Estimating Latin American Student Workload, from the perspective of professors and students" was conducted. It aimed to provide an overview of the total workload (in hours) that a student needs in

14 Pablo Beneitone et al., eds., Reflexiones y Perspectivas de la Educación Superior en América Latina. Informe Final -Proyecto Tuning-América Latina. 2004 - 2007 (Bilbao: University of Deusto and University of Groningen, 2007), 293. 
order to pass the courses provided in these 15 subject areas. The survey was based on both the perceptions of what professors and students consider as the time required for, or spent on, the acquisition of learning outcomes in the related courses. A total of 10,086 questionnaires were collected. As its major result, the survey provided a fair estimate of the annual workload of Latin American students.

It is worth noting that the estimation of student workload was not based on contact hours only (i.e. hours spent by students on activities guided by teaching staff). It embraced all the learning activities required to achieve the expected learning outcomes, including the time spent on independent work (seminar or laboratory work; collection and selection of relevant material; study of the material; writing of papers/projects/dissertation; practical work, among other activities) and the preparation for assessment as well as the time necessary to undergo the assessment procedure.

According to the responses of students and professors, the total time required for students to meet the demands of an academic year (including contact and non-contact hours) is, on average, 1,247 hours per academic year. The survey showed however a significant variation among countries which fluctuated between 921 and 1,646 hours per year. In most of Latin American higher education institutions (12) student workload ranges from 1,200 to 1,400 hours per academic year. Table 1 shows the estimated student workload by country of origin.

As seen, in Latin America, the length of the academic year differs from one country to another and, in some countries, even from one university to another. Its duration, as said before, comprises the number of hours dedicated to classwork, the number of weeks dedicated to independent study and field work, the time to prepare tests and exams, and the number of weeks to carry out examination procedures. All these elements amount to the specific length of the academic period, information that can be used to draw a comparison by discipline and/or country.

This estimation of the academic year takes also into account the vacation periods, when students are expected to continue working and preparing assessments, projects and dissertations. In most of Latin American higher education institutions the length of the academic semester ranges from 16 to 20 weeks. To have an annual perspective of this length it is necessary to double these figures.

An estimation of the annual student workload by subject area (Table 2) also shows a significant annual variability ranging from 861 hours in Law to 1,589 hours in Architecture. Again, in the majority of the subject areas (9) the student workload ranges from 1,200 to 1,400 hours per academic year. 
Table 1

Estimated student workload by country of origin

\begin{tabular}{|c|c|c|c|c|}
\hline & $\begin{array}{l}\text { Estimation } \\
\text { of professors } \\
\text { on the total } \\
\text { workload of } \\
\text { one semester } \\
\text { (in hours) }\end{array}$ & $\begin{array}{l}\text { Estimation of } \\
\text { students on the } \\
\text { total workload } \\
\text { of one semester } \\
\text { (in hours) }\end{array}$ & $\begin{array}{l}\text { Average on the } \\
\text { estimations of } \\
\text { professors and } \\
\text { students on the } \\
\text { total workload } \\
\text { of a semester } \\
\text { (in hours) }\end{array}$ & $\begin{array}{l}\text { Average on the } \\
\text { estimations of } \\
\text { professors and } \\
\text { students on the } \\
\text { total workload } \\
\text { of an academic } \\
\text { year (in hours) }\end{array}$ \\
\hline Nicaragua & 624.25 & 296.76 & 460.51 & 921.01 \\
\hline Honduras & 457.35 & 479.62 & 468.49 & 936.97 \\
\hline Panama & 564.5 & 443.17 & 503.84 & 1007.67 \\
\hline Chile & 613.81 & 497.2 & 555.51 & 1111.01 \\
\hline Bolivia & 602.6 & 574.74 & 588.67 & 1177.34 \\
\hline Venezuela & 473.39 & 727.06 & 600.23 & 1200.45 \\
\hline Peru & 612.67 & 605 & 608.84 & 1217.67 \\
\hline Brazil & 650.13 & 570.42 & 610.28 & 1220.55 \\
\hline Uruguay & 574.27 & 679.76 & 627.02 & 1254.03 \\
\hline Guatemala & 586.89 & 682.21 & 634.55 & 1269.1 \\
\hline Paraguay & 599.5 & 709 & 654.25 & 1308.5 \\
\hline Costa Rica & 667.92 & 658.84 & 663.38 & 1326.76 \\
\hline Mexico & 603.63 & 730.01 & 666.82 & 1333.64 \\
\hline Ecuador & 694.25 & 650.2 & 672.23 & 1344.45 \\
\hline Colombia & 683.14 & 673.33 & 678.24 & 1356.47 \\
\hline El Salvador & 783 & 604.86 & 693.93 & 1387.86 \\
\hline Argentina & 740.57 & 697.47 & 719.02 & 1438.04 \\
\hline Cuba & 932.06 & 714.87 & 823.47 & 1646.93 \\
\hline
\end{tabular}

Source: Tuning Latin America project. 
Table 2

Estimated student workload by subject area

\begin{tabular}{|c|c|c|c|c|}
\hline & $\begin{array}{l}\text { Estimation } \\
\text { of professors } \\
\text { on the total } \\
\text { workload of } \\
\text { one semester } \\
\text { (in hours) }\end{array}$ & $\begin{array}{l}\text { Estimation } \\
\text { of students } \\
\text { on the total } \\
\text { workload of } \\
\text { one semester } \\
\text { (in hours) }\end{array}$ & $\begin{array}{c}\text { Average } \\
\text { on the } \\
\text { estimations } \\
\text { of professors } \\
\text { and students } \\
\text { on the total } \\
\text { workload of } \\
\text { a semester (in } \\
\text { hours) }\end{array}$ & $\begin{array}{l}\text { Average } \\
\text { on the } \\
\text { estimations } \\
\text { of professors } \\
\text { and students } \\
\text { on the total } \\
\text { workload of } \\
\text { an academic } \\
\text { year (in hours) }\end{array}$ \\
\hline Law & 425.59 & 435.54 & 430.57 & 861.13 \\
\hline Psychology & 545.47 & 463.05 & 504.26 & 1008.52 \\
\hline Nursing & 597.43 & 423.71 & 510.57 & 1021.14 \\
\hline History & 560 & 515.43 & 537.72 & 1075.43 \\
\hline Education & 575.86 & 509.82 & 542.84 & 1085.68 \\
\hline Business & 681.1 & 529.08 & 605.09 & 1210.18 \\
\hline Mathematics & 525.25 & 753.39 & 639.32 & 1278.64 \\
\hline $\begin{array}{l}\text { Agricultural } \\
\text { Sciences }\end{array}$ & 677.41 & 623.58 & 650.5 & 1300.99 \\
\hline $\begin{array}{l}\text { Information } \\
\text { Technology }\end{array}$ & 663.73 & 690.56 & 677.15 & 1354.29 \\
\hline Physics & 683 & 679.46 & 681.23 & 1362.46 \\
\hline Chemistry & 676.8 & 692.15 & 684.48 & 1368.95 \\
\hline Civil Engineering & 695.51 & 689.97 & 692.74 & 1385.48 \\
\hline Geology & 743.71 & 646.36 & 695.04 & 1390.07 \\
\hline Medicine & 606.33 & 807.7 & 707.02 & 1414.03 \\
\hline Architecture & 871.63 & 718.31 & 794.97 & 1589.94 \\
\hline
\end{tabular}

Source: Tuning Latin America project.

The collected data also provide information on the so perceived student workload per week, which could mean a step closer to the overall calculation. 
Besides, it was also found that there is a wide variability in the duration in weeks of the academic year by country. This variation ranges from 32 to 40 weeks depending on the country. Thus, Table 3 consolidates the average estimation of professors and students in each subject area over the total student workload per week (including contact hours as well independent activities). The average weekly student workload would be 50 hours.

Table 3

Estimated student workload per week by subject area

\begin{tabular}{|l|c|}
\hline & $\begin{array}{c}\text { Average on the estimations of professors } \\
\text { and students on the total workload per } \\
\text { week (in hours) }\end{array}$ \\
\hline Law & 39.87 \\
\hline Business & 42.26 \\
\hline Geology & 43.64 \\
\hline Chemistry & 46.34 \\
\hline Psychology & 46.71 \\
\hline Physics & 49.58 \\
\hline Civil Engineering & 50.94 \\
\hline Agricultural Sciences & 51.01 \\
\hline History & 52.12 \\
\hline Information Technology & 52.26 \\
\hline Mathematics & 53.8 \\
\hline Nursing & 53.93 \\
\hline Education & 55.93 \\
\hline Architecture & 57.56 \\
\hline Medicine & 59.12 \\
\hline
\end{tabular}

Source: Tuning Latin America project.

There are other important features that need to be looked at when reflecting on the student workload. As already said, a large number of interrelated factors are involved in the achievement of the desired learning outcomes. These are not restricted to the number of student work hours and to the student's intelligence and speed, but also include the teaching and learning methods. It makes a great difference when teaching is organised into smaller groups as opposed to its organisation into larger ones. It does also 
make a difference depending on the type of learning activity in which the student is involved (contact classes, seminars, practical courses or practical exercises). Moreover, the existence or non existence of a system of tutorials might influence the learning outcomes.

The study emphasizes the estimation of non-contact time that students require to meet academic obligations and on the learning activities they should or actually develop in order to attain learning outcomes (readings, field work, exam preparation, virtual activities, etc.). Collected data (Figure 1) show that both professors and students respond positively (over $80 \%$ ) to the topic if they did reading activities in the non-contact time. However, in analysing this element in detail, it is worth noting that reading activity is more valued by professors than students. In almost all areas the professors' perception of this activity has a higher percentage of affirmative responses. In some cases, professor's perception doubles that of the student's (Business, Architecture, Education).

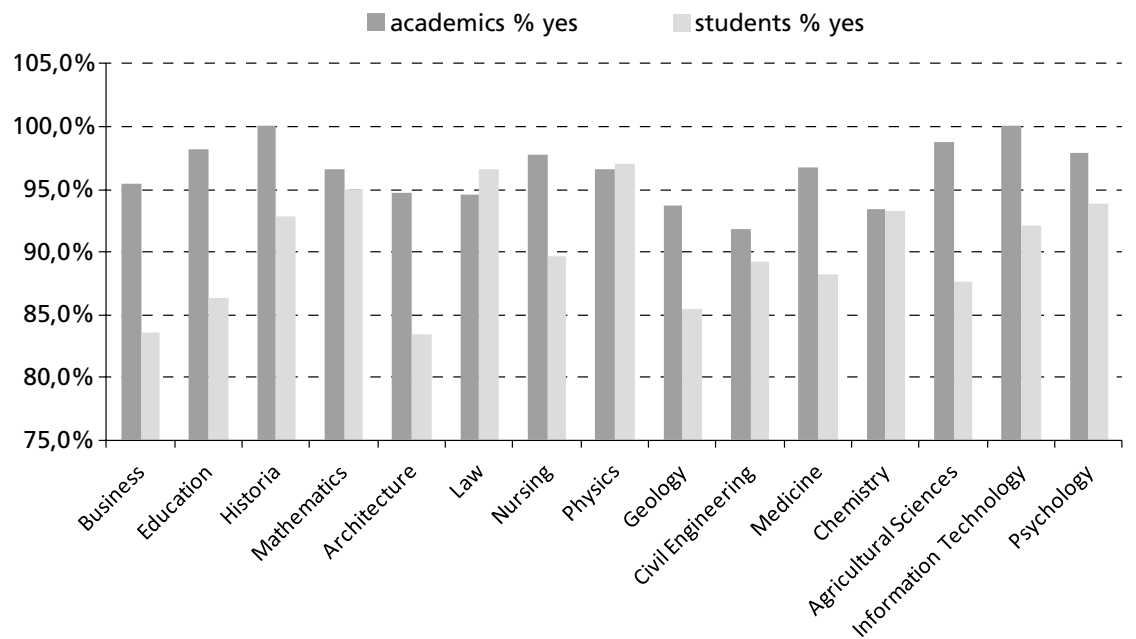

Figure 1

Percentage of positive responses from students and professors about reading activities at non-contact time by subject area.

Comparatively, when asked if they did virtual activities (chat, virtual classroom, forum, etc.) in non-contact time, the positive responses from both students and professors descend significantly (Figure 2). 


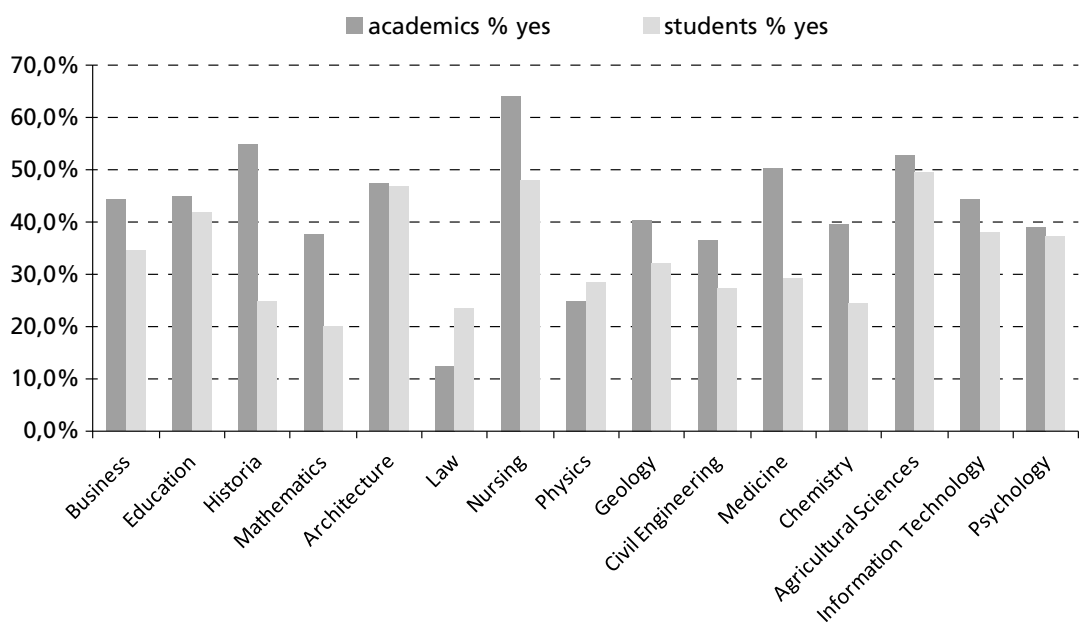

Figure 2

Percentage of positive responses from students and professors about virtual activities at non contact time by subject area.

The survey also questioned students and professors about the existence of planning associated with non-contact work time. The answers again show a significant gap between the perception of professors and students (Figure 3). In most subject areas, professors state that they planned non-contact hours student workload. Students, however, do not acknowledge to have planned, in an autonomous fashion, learning activities to be done outside the classroom environment.

Figure 4 makes clear that despite manifest positively planning, as seen in the responses, there seems to be no significant contrast between that planning and the real time that students require to perform the learning activities.

This study on Latin American student workload is meaningful. It signifies a fundamental discussion base for the subsequent definition and implementation of a reference credit system for the region. One of the main conclusions that can be drawn from it is that the rich diversity of its results - as seen in the differences between countries - does not inhibit the suggestion of a shared approach to measure student workload throughout Latin America. The resulting proposal emphasizes on a common and flexible approach which, while respecting existing Latin American higher education diversity and local and national autonomy, can facilitate curricular change and innovation, provide greater accountability, and build linkages between the different higher education systems at a regional level. 


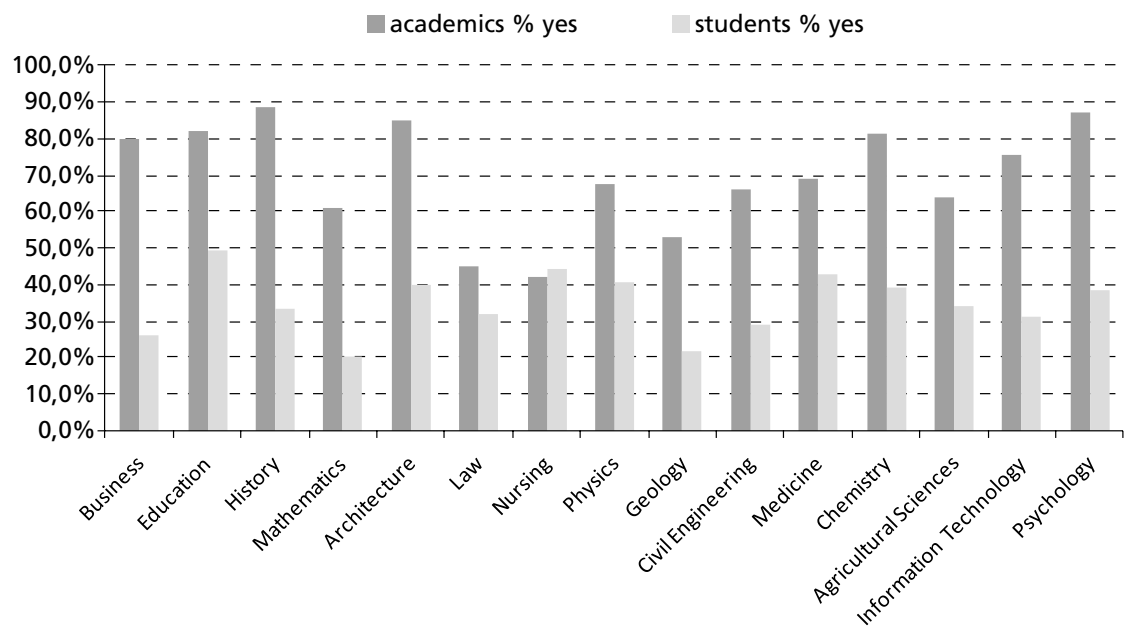

Figure 3

Percentage of positive responses from students and professors about preparing academic work plan by subject area.

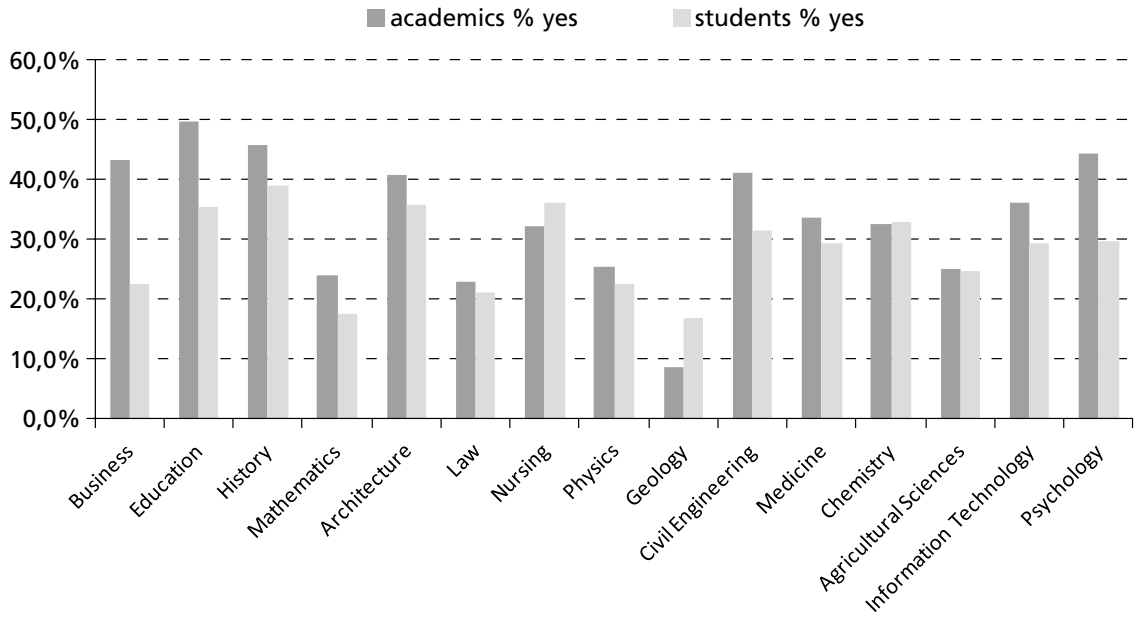

Figure 4

Have you contrasted the academic work plan with your professor/ students? by subject area. 


\section{The Latin American Reference Credit (CLAR - Crédito Latinoamericano de Referencia)}

The Tuning Latin America project began discussing the need for an academic credit system at the regional level ever since the first phase of its development (2004-2007). These discussions were initially developed at the level of the National Tuning Centre ${ }^{15}$ and led to agreements embodied in the Tuning Final Report 2004-2007. These determined that the future Latin American Credit should include the total student workload to obtain the expected learning outcomes. A system of this nature should be based on the correlation of a number of elements:

- The degree profile, which sets out the competences to be developed.

- The level and existing admission requirements.

- The learning outcomes specified for each module/section/course.

- The educational activities that best ensure that the learning outcomes will be achieved.

- The types of assessment considered most appropriate for the learning outcomes.

- The time (measured in hours), based on the student workload, which on average will be needed to perform the educational activities that are necessary for achieving the learning outcomes (Beneitone, 2007). ${ }^{16}$

In the second phase of Tuning Latin America Project (2011-2013), the commitment to move forward and create a credit system for the region has been much more concrete. The new phase of the project in fact focuses on the role of student workload, and seeks to stress its relationship with competences and learning outcomes.

Unlike other proposals, CLAR credit has been born out of the importance of disseminating and promoting a curricular paradigm shift in Latin American higher education institutions and of the necessity to assure the quality of

15 Tuning Latin America project has encouraged the setting up of National Tuning Centres in each of the Latin American countries involved in the project with the aim of promoting the participation of universities that cannot be directly involved in it. These centres are led by officials responsible for higher education issues in their respective countries, or by members of national quality assurance agencies, higher education authorities (Rectors, Vicerectors), or professional/student/university associations etc. These centres must link the Tuning project with others nationally, and provide Tuning Project with the information about national education systems that the project may demand.

${ }^{16}$ Pablo Beneitone et al., eds., Reflexiones y Perspectivas de la Educación Superior en América Latina, 292. 
programs of professional training while encouraging mobility of students at a regional level. Without restricting complementary goals, CLAR credit's main objectives are:

- Encourage the development of a curriculum reform that considers the credit system as an improvement of a degree profile focused on student-centred learning and as a recognition factor of the accumulation of academic work.

- Promote the quality of the professional training process. Despite CLAR not being responsible for quality assurance, a credit system well designed and balanced and with a clear connection to competences and degree profiles should positively affect and increase quality.

- Facilitate mobility of students from country to country in Latin America from a common recognition of the student's academic work.

In a complementary perspective, CLAR credit seeks to represent the relative complexity of the various curricular components and facilitate the evaluation and comparison of learning outcomes in different contexts of qualifications, programs and learning environments. It also seeks to provide a method for comparing shared learning among different academic programs, sectors, regions and countries.

As for its concept, CLAR credit is conceived as a unit of value that estimates the amount of work measured in hours that a student requires to achieve learning outcomes and pass a course or a semester. ${ }^{17}$ Generally speaking, a learning outcome describes what a student should know, understand and be able to do after successful completion of a process of learning.

CLAR credit is based on the principle that 60 credits measure the workload of a full-time student during one academic year. ${ }^{18}$ The use of this normalizer was adopted at the Second General Meeting of Tuning Latin America project, taking into account:

a) Its divisible character, which allows for an easy adjustment to different modalities of organization of the academic year (semester, quarter, trimester, modules, etc.).

b) Its compatible character. There are affinities between CLAR credit and other credit systems that are widely used in other regions of the world. ${ }^{19}$

17 Tuning Latin America Project (Tuning Latin America), CLAR. Latin American Reference Credit (Bilbao: University of Deusto, 2013).

${ }_{18}$ Agreements reached at the Second General Meeting - Tuning Latin America Project - Guatemala, 18 - 20 November 2011.

${ }^{19} 60$ credits per year is used in Europe (ECTS) and in Asia (ACTS) 
c) If as a rule one full time academic year is equivalent to 60 credits, a semester is equivalent to 30 credits. Thus, a four-year degree programme, according to this CLAR credit proposal, is equal to 240 credits, a five-year programme amounts to 300 credits, and six years to 360 credits - in accordance with the reality of courses and degree programmes in different countries.

For the purposes of calculating the value of CLAR credit, two elements have been considered: the duration of the academic year and the annual student workload.

1) The duration of the academic year: This is one of the main factors that influence the volume of annual student workload and help determine the value of a credit. As demonstrated by the "Estimation Study in Latin America", the duration of one academic year may vary from country to country and even change in the same country from one institution to the other. In the first phase of Tuning Latin America, and based on the data provided by the National Tuning Centres, the Fourth General Meeting of the Project (Brussels, June 2006) concluded that in the majority of higher education institutions in Latin America the length of the academic year ranged from 32 to 40 weeks. This finding was supported in the study mentioned before, which was conducted between November 2011 and March 2012.

To calculate CLAR credit, 36 weeks - corresponding to the midpoint of the interval detected between 32 and 40 weeks - was considered as a reference figure.

2) The annual student workload. The volume of time, measured in hours, that a student requires to reach the expected learning outcomes and develop the competences stated in the programme profile, also exhibits a large dispersion and variability in Latin America, among countries and within. The number of hours that students need to achieve learning outcomes is variable and depends - as previously stated - on individual skills, experience and training of lecturers, methods and approaches of teaching, learning and assessment developed, nature and consistency of the curriculum, the quality of the organization, the availability of learning resources, institutional traditions at a national and regional level, etc.

In the definition of CLAR credit student workload is central. The weekly student workload in Latin America ranges from 40 to 55 hours, as established by the results provided by the study on "Estimating student workload in Latin America". Ascribing a longer weekly volume to student workload is not only unrealistic but ignores the hours of leisure, rest, and dedication to other activities and social interactions that the students deem important. 
Considering the length of the academic year -36 weeks a year - and the range of weekly student working hours (40-55 hours), the annual student workload would range from 1,440 to 1,980 hours.

\begin{tabular}{|c|c|c|}
\hline Weeks a year & $\begin{array}{c}\text { Student Workload } \\
\text { per week }\end{array}$ & $\begin{array}{c}\text { Student Workload } \\
\text { per year }\end{array}$ \\
\hline 36 weeks & 40 hours & 1440 hours \\
\hline 36 weeks & 55 hours & 1980 hours \\
\hline
\end{tabular}

The above figures lead to a CLAR credit whose value is to fluctuate according to the following estimation:

(1, $440 \mathrm{hrs}$. / Year $):(60$ credits $/$ year $)=24 \mathrm{hrs}$. / Credit

(1,980 hrs. / Year): $(60$ credits / year $)=33 \mathrm{hrs}$. / Credit

Therefore a CLAR credit has no unique temporal value. Its value ranges from 24 to 33 hours.

In those countries where the academic year has a length different from 36 weeks, the number of weekly student working hours will vary. Yet, this difference will not alter the annual operating range defined in Table above $(1,440-1,980)$. Any variation in the number of weeks, and in the number of working hours per week, must respect the range established so as to avoid excessive variability in CLAR credit.

\section{Some conclusions}

There is clear evidence from recent social, economic and political movements in Latin American that our societies need educated citizens to face the challenges posed by the present as well as the future. Our countries need to direct their own destinies wisely and satisfactorily and to assume the role they need to play in pursue of cultural, intellectual and productive development. Given their role in society, universities are the best-equipped organisations to play a key function in designing and implementing suitable strategies for achieving these goals. They have the mission, and above all, the basic responsibility to use their knowledge, their tradition and their capacity in favour of development and innovation.

In this new context, students have to take an active part in building their own learning so that they can act individually as well as collectively in the construction of the future. Yet, close to the new student should be the new professor, the one who provides the resources (information, 
methods, tools), design creative learning environments and assists and motivates students throughout the entire learning process. The inspirational professor should become a ubiquitous representation of a paradigm shift, enabling processes of students' human development and acting as a methodological advisor and facilitator. In this new proposal the reflection on student workload is fundamental to students' effective learning and to their proper growth as responsible, capable, resourceful and moral human beings.

CLAR credit can help to focus on the students and on the quality and relevance of competences that must be developed for their proper integration into society. It can also facilitate the measurement of actual hours used by the students and promote reflection on the type of learning activities that they require to achieve learning outcomes and develop their skills in a particular degree programme. As an accumulation system, CLAR credit can not only facilitate recognition procedures but also open the possibility for flexible learning paths and thus facilitate access to higher education for non-traditional learners. By promoting a system of recognition and development of the quality of academic work, CLAR credit will encourage curricular innovation and continuous improvement of the quality of programs in national systems.

The use of CLAR credit as a transfer as well as an accumulation system will also contribute to the building of a common higher education area in Latin America. A credit system of this kind will be beneficial for achieving more transparency and compatibility between different national educational structures and facilitate students' transit and mobility from one country to another by bringing greater efficiency in the process of academic recognition of courses taken in mobility experiences. It is assumed also that CLAR credit will not only permit students' mobility between Latin American countries and also a fertile dialogue with other international higher education systems existing in Europe, North America, Asia, Africa and Australia.

Further, CLAR credit's greater impact lies in the possibility that by defining - through its application - a higher education common space, a greater understanding, collaboration and integration in Latin America will be put in place. This, in turn, will help to create a culture of friendship and peace among countries linked together by common cultural and historical backgrounds and entwined by shared interests and aspirations. 


\section{Bibliography}

Arocena, Rodrigo, and Judith Sutz. "Changing Knowledge Production and Latin American Universities." Research Policy 30, no. 8 (2001): 1221 - 34.

Beneitone, Pablo, César Esquetini, Julia González, Maida María Marty Maleta, Gabriela Siufi, and Robert Wagenaar, eds. Reflexiones y Perspectivas de la Educación Superior en América Latina. Informe Final -Proyecto TuningAmérica Latina. 2004-2007. Bilbao: University of Deusto and University of Groningen, 2007.

Brunner, José J. "Aseguramiento de la Calidad y Nuevas Demandas sobre la Educación Superior en América Latina.” In Educación Superior. Desafío Global y Respuesta Nacional, edited by Luis Enrique Orozco. Bogotá: Universidad de los Andes, 2001.

Consejo de Rectores de Universidades Chilenas (CRUCH). Guía Práctica para la Instalación del Sistema de Créditos Académicos Transferibles (SCT-Chile). Santiago de Chile: MECESUP, 2007.

Cullen, Carlos. "El Debate Epistemológico de fin de Siglo y su Incidencia en la Determinación de las Competencias Científico Tecnológicas en los Diferentes Niveles de la Educación Formal. Parte II." In Novedades Educativas $N^{\circ} 62$. Buenos Aires, 1996. http://www.oei.es/n4003.htm.

Everwijn, S.E.M., G.B. Bomers, and J.A. Knuben. "Ability or Competence-Based Education: Bridging the Gap between Knowledge Acquisition and Ability to Apply." Higher Education 25, no. 4 (1993): 425-38.

Gardner, Howard. Inteligencias Múltiples. La Teoría en la Práctica. Barcelona: Paidós, 1995.

Gil, Antonio Carlos. Didática do Ensino Superior. $1^{\text {st }}$ ed. São Paulo: Atlas, 2008.

Kouwenhoven, Wim. "Competence-Based Curriculum Development in Higher Education: A Globalised Concept?” In Technology Education and Development, edited by Aleksandar Lazinica and Carlos Calafate. Vukovar (Croatia): In-Tech, 2009. http://www.intechopen.com/books/technology-education-anddevelopment/competence-based-curriculum-development-in-higher-educationa-globalised-concept-.

Malan, SPT. "The 'New Paradigm' of Outcomes-Based Education in Perspective." Tydskrif vir Gesinsekologie en Verbruikerswetenskappe (Journal of Family Ecology and Consumer Sciences) 28 (2000): 22 - 28.

Mockus, Antanas. "Epílogo: El Debilitamiento de las Fronteras de la Escuela.” In Las Fronteras de la Escuela. Santa Fé de Bogotá: Cooperativa Editorial Magisterio, 1997.

Orozco Silva, Luis Enrique. "Calidad Académica y Relevancia Social de la Educación Superior en América Latina." Revista Iberoamericana de Educación Superior (RIES) 1, no. 1 (2010): 24-36.

Reddy, K. "The Inclusion of Technology as a Subject in the National Curriculum. A Significant Paradigm Shift for Education in South Africa." MEd thesis, University of Pretoria, 1995. 
Tuning Latin America Project (Tuning Latin America). CLAR. Latin American Reference Credit. Bilbao: University of Deusto, 2013.

. "Working Papers - Tuning Latin America Document 2." 2nd General Meeting. Guatemala, 18-20 November 2011. http://www.tuningal.org/es/ publicaciones/cat_view/42-presentaciones-reunion-guatemala-16-19-nov-2011. - "Working Papers - Tuning Latin America Document 4. CLAR Final Document." 4th General Meeting. Brussels, 19-22 November 2012. http://www. tuningal.org/es/publicaciones/cat_view/44-presentaciones-reunion-bruselas-1922-nov-2012. 